\title{
ROLE OF OSTEOPONTIN AND DIKKOPF RELATED PROTEIN -1(DKK-1) AS DIAGNOSTIC MARKERS OF HCV RELATED HEPATOCELLULAR CARCINOMA
}

\author{
By

\begin{abstract}
Abdellah A. Omar ${ }^{1}$, Ashraf T. Abd Elmouttaleb ${ }^{2}$, Ebrahim M. Bayomy ${ }^{3}$ and Gamal M. Soliman ${ }^{4}$
\end{abstract} \\ ${ }^{1}$ Medical Biochemistry Department, Faculty of Medicine, Al-azhar University. \\ ${ }^{2}$ Medical biochemistry Department Assisted Reproductive unit, International Islamic \\ Center for Population Studies and Research, Al-Azhar University \\ ${ }^{3}$ Clinical Pathology Department, Faculty of Medicine, Al-Azhar University \\ ${ }^{4}$ Tropical Medicine Department, Faculty of Medicine, Al-Azhar University.
}

\begin{abstract}
Background: Osteopontin (OPN) is an important tumor marker, since it presents as an immobilized extracellular matrix molecule in addition to be present as a secreted form in body fluids involving plasma. Osteopontin levels in the plasma were found to be significantly higher in hepatocellular Carcinoma (HCC) patients than in healthy control individuals and also higher than in patients with chronic liver diseases. Dikkopf related protein-1 (DKK-1) is a diagnostic and prognostic serologic marker for early HCC. The DKK-1 mRNA and protein levels were found to be up regulated in early HCC.
\end{abstract}

Study design: This is a retrospective case control study.

Objective: The aim of the present study was to evaluate the role of serum OPN level and Dickkopf-1(DKK1) as potential markers of HCC among HCV infected patients, compared to alpha fetoprotein (AFP). Also, its relationship with clinicopathological features of HCC patients.

Subjects and Methods: The study included 90 adult subjects; they were classified into 3 groups. Group1: It included 30 patients with HCC. Group 2: It included 30 patients with chronic liver disease (CLD) (chronic hepatitis $\mathrm{C}$ without $\mathrm{HCC}$ ), and Group 3: It included 30 apparently healthy individuals as a control group. Serum Osteopontin and Dikkopf related protein -1(DKK-1) were measured by Enzyme-linked immunosorbent assay ELISA.

Results: There were highly statistical significant differences between the three groups as regard serum Dikkopf related protein -1 and Osteopontin levels $(\mathrm{p}<0.001)$. DKK1 and OPN levels were significantly higher in metastasis cases than non-metastatic cases $(\mathrm{p}<0.001)$, while AFP level was non-significant $\mathrm{P}=$ 0.424. Patients with large tumor size have significantly higher OPN levels $\mathrm{p}=0.025$, while nonsignificantlydifferent as regard AFP and DKK1 levels.

Conclusion: OPN and DKK1 can be used for diagnosis of HCC and differentiation between HCC and CLD. OPN and DKK1 have higher sensitivity and specificity than AFP and can be used for early diagnosis. Combination between OPN and DKK1 has increased both sensitivity and specificity for detection of of HCC.

Keywords: Hepatocellular carcinoma, chronic liver disease, Osteopontin, Dickopf related protein- 1. 


\section{INTRODUCTION}

Infection with Hepatitis C Virus (HCV) is the major factor associated with $\mathrm{HCC}$ mainly through indirect chronic inflammation, cell death and proliferation. The markers of HCV infection are present in the serum of $80 \%$ of patients with HCC (Lehman and Wilson, 2009).

Hepatocellular carcinoma is a major health problem in Egypt and its incidence is increasing. The high prevalence of $\mathrm{HCV}$ infection makes screening programs and surveillance of those patients a very important tool to early detect cases of small HCCs (Shaker et al., 2013).

Osteopontin (OPN) is a glycophosphoprotein with cytokine and chemokine properties that was found to be circulating in the biological fluids of healthy individuals, but elevated in cancer patients as well as in individuals with systemic inflammatory response syndrome (Yang et al., 2014).

Osteopontin was found to be highly expressed in many malignancies and the expression level of OPN in tumor tissues or in blood of cancer patients has been positively correlated with tumor grade, tumor stage and early recurrence in many cancer types (Sun et al., 2011).

DKK-1 is a diagnostic and prognostic serologic marker for early HCC. The DKK-1 mRNA and protein levels were found to be up regulated in early HCC. Serum levels of DKK-1 in patients with early HCC were significantly elevated. DKK-1 had a better sensitivity and accuracy than AFP. More importantly, $73.1 \%$ of the patients negative for AFP could be diagnosed with early HCC using
DKK-1. A combination of DKK-1 and AFP further improved the diagnostic efficacy (Yang et al., 2012).

The aim of the present study was to evaluate the role of serum OPN and Dickkopf-1(DKK1) levels as potential markers of HCC among HCV infected patients, compared to alpha fetoprotein (AFP).

\section{SUBJECTS AND METHODS}

This study was carried out in the Medical Biochemistry and Tropical Medicine Departments between October 2016 and August 2017, AL-Azhar University. A written informed consent was taken from the patients participated in this study. Approval for the study was obtained from the research Ethics Committee, Faculty of Medicine, AlAzhar University and patients were recruited amongst those attending the Tropical Medicine Department in AlHussein University Hospital.

Subjects: The study included 90 adult subjects; they were 57 males and 33 females. They were classified into 3 groups:

Group 1: It included 30 patients with HCC; 18 males (60\%) and 12 females $(40 \%)$. In $15(50 \%)$ of patients the primary HCC lesion was less than $5 \mathrm{~cm}$ and in the remaining 15 patients $(50 \%)$ was more than $5 \mathrm{~cm} .21(70 \%)$ of patients showed HCC metastases and 9 patients $(30 \%)$ showed no HCC metastases.

Group 2: It included 30 patients with CLD (chronic hepatitis C without HCC); 21 males $(70 \%)$ and 9 females $(30 \%)$. 
ROLE OF OSTEOPONTIN AND DIKKOPF RELATED PROTEIN -1(DKK-1) AS... 61

Group 3: Included 30 apparently healthy individuals (control group); 18 males $(60 \%)$ and 12 females (40\%).

\section{Exclusion criteria:}

1. Patients having extra hepatic malignancy.

2. Patients having any bony lesions or inflammatory diseases.

3. Patients with any chronic liver disease other than HCV.

All individuals included in this study were subjected to the following:

1. Full history taking focusing on previous hepatic disorders, predisposing factors preceding liver disease, age, sex, alcohol intake and blood transfusion.

2. Thorough clinical examination, with special emphasis on abdominal examination, jaundice, edema and ascites.

3. laboratory investigations: Complete blood count, liver and kidney functions, Hepatitis markers, AFP, Osteopontin and Dikkopf related protein-1.

4. Imaging studies:

- Abdominal ultrasonography for all patients (liver, spleen, portal vein, ascites).

- Triphasic computed tomography for HCC group (HCC size, number, site, portal vein thrombosis).

\section{Sample Preparation:}

$5 \mathrm{ml}$ of venous blood was collected in a plain vacutainer tube and allowed to clot,then the serum was separated by centrifugation at 3000 r.p.m for 15 minutes and used for routine laboratory investigations, AFP, Osteopontin and Dickkopf related protein-1 measurement . Analytical Methods:

\section{A) Hepatitis markers:}

For HBsAg: The analysis of serum HBsAg was done by electrochemiluminescence immunoassay "ECLIA" on the cobas e 411 immunoassay analyzer from Roche diagnostics.

For anti HCV antibody: The analysis of serum anti HCV antibody was done by "ECLIA" on the cobas e 411 immunoassay analyzer.

B) Serum AFP: The analysis of serum AFP was done "ECLIA" on Cobas e 411 system from cobas.

C) Serum Osteopontin assay: Serum osteopontin levels were determined and measured by (ELISA) using ChromateELISA reader Diagnostics (USA) using sunred ELISA kit(China).

D) Serum Dickkopf assay: Serum Dickkopf1 levels were determined and measured by Chromate ELISA reader Diagnostics (USA) using Sunred ELISA kit(China).

STATISTICAL ANALYSIS: Data collected throughout history, basic clinical examination, laboratory investigations and outcome measures coded, entered and analyzed using Microsoft Excel software. Data were then imported into Statistical Package for the Social Sciences (SPSS version 20.0) (Statistical Package for the Social Sciences) software for analysis. Quantitative data were represented as number and percentage, mean $\pm \mathrm{SD}$, the following tests were used in parametric quantitative independent groups which 
were Student t- test in non-parametric normally distributed data while skewed data by Mann Whitney. Differences and association of qualitative variables between two groups by Chi square test $\left(\mathrm{X}^{2}\right)$.While between multiple groups by one way ANOVA for normally distributed data followed by Tukeys post hoc test, correlation by Pearson's or Spearman's correlation. $\mathrm{P}$ value was set at $<0.05$ for significant results and $<0.001$ for high significant result.

ROC curve:

A receiver operating characteristic (ROC), or simply ROC curve, is a graphical plot which illustrates the performance of a binary classifier system as its discrimination threshold is varied. It was used for determination of cut off values of AFP, OPN and DKK1 for diagnosis of HCC.

\section{RESULTS}

There were significant differences among studied groups as regard clinical characters, i.e. encephalopathy, ascites, edema, portal vein thrombosis and jaundice (Table 1).

Table (1): Statistical comparison of clinical findings among studied groups.

\begin{tabular}{|c|c|c|c|c|c|c|c|}
\hline & \multicolumn{3}{|c|}{ GROUPS } & \multirow[t]{2}{*}{ Total } & \multirow[t]{2}{*}{$\mathbf{P}$} \\
\hline & & & Control & CLD & HCC & & \\
\hline \multirow[t]{4}{*}{ Encephalopathy } & \multirow[t]{2}{*}{ No } & $\mathbf{N}$ & 30 & 18 & 9 & 57 & \multirow{4}{*}{$\begin{array}{c}\mathrm{P}_{1}<0.001 \\
\mathrm{P}_{2} \\
<0.001 \\
\mathrm{P}_{3}<0.001\end{array}$} \\
\hline & & $\%$ & $100.0 \%$ & $60.0 \%$ & $30.0 \%$ & $63.3 \%$ & \\
\hline & \multirow{2}{*}{ Yes } & $\mathbf{N}$ & 0 & 12 & 21 & 33 & \\
\hline & & $\%$ & $0.0 \%$ & $40.0 \%$ & $70.0 \%$ & $36.7 \%$ & \\
\hline \multirow[t]{4}{*}{ Ascites } & \multirow[t]{2}{*}{ No } & $\mathbf{N}$ & 30 & 9 & 6 & 45 & \multirow{4}{*}{$\begin{array}{c}\mathrm{P}_{1}<0.001 \\
\mathrm{P}_{2}<0.001 \\
\mathrm{P}_{3}<0.05\end{array}$} \\
\hline & & $\%$ & $100.0 \%$ & $30.0 \%$ & $20.0 \%$ & $50.0 \%$ & \\
\hline & \multirow[t]{2}{*}{ Yes } & $\mathbf{N}$ & 0 & 21 & 24 & 45 & \\
\hline & & $\%$ & $0.0 \%$ & $70.0 \%$ & $80.0 \%$ & $50.0 \%$ & \\
\hline \multirow[t]{4}{*}{ Edema } & \multirow[t]{2}{*}{ No } & $\mathbf{N}$ & 30 & 9 & 3 & 42 & \multirow{4}{*}{$\begin{array}{l}\mathrm{P}_{1}<0.001 \\
\mathrm{P}_{2}<0.001 \\
\mathrm{P}_{3}<0.001\end{array}$} \\
\hline & & $\%$ & $100.0 \%$ & $30.0 \%$ & $10.0 \%$ & $46.7 \%$ & \\
\hline & \multirow[t]{2}{*}{ Yes } & $\mathbf{N}$ & 0 & 21 & 27 & 48 & \\
\hline & & $\%$ & $0.0 \%$ & $70.0 \%$ & $90.0 \%$ & $53.3 \%$ & \\
\hline \multirow{4}{*}{$\begin{array}{l}\text { Portal vein } \\
\text { thrombosis }\end{array}$} & \multirow[t]{2}{*}{ No } & $\mathbf{N}$ & 30 & 27 & 12 & 69 & \multirow{4}{*}{$\begin{array}{c}\mathrm{P}_{1}<0.05 \\
\mathrm{P}_{2}<0.001 \\
\mathrm{P}_{3} \\
<0.001\end{array}$} \\
\hline & & $\%$ & $100.0 \%$ & $90.0 \%$ & $40.0 \%$ & $76.7 \%$ & \\
\hline & \multirow[t]{2}{*}{ Yes } & $\mathbf{N}$ & 0 & 3 & 18 & 21 & \\
\hline & & $\%$ & $0.0 \%$ & $10.0 \%$ & $60.0 \%$ & $23.3 \%$ & \\
\hline \multirow[t]{4}{*}{ Jaundice } & \multirow[t]{2}{*}{ No } & $\mathbf{N}$ & 30 & 12 & 9 & 51 & \multirow{4}{*}{$\begin{array}{c}\mathrm{P}_{1}<0.001 \\
\mathrm{P}_{2} \\
<0.001 \\
\mathrm{P}_{3}<0.05\end{array}$} \\
\hline & & $\%$ & $100.0 \%$ & $40.0 \%$ & $30.0 \%$ & $56.7 \%$ & \\
\hline & \multirow[t]{2}{*}{ Yes } & $\mathbf{N}$ & 0 & 18 & 21 & 39 & \\
\hline & & $\%$ & $0.0 \%$ & $60.0 \%$ & $70.0 \%$ & $43.3 \%$ & \\
\hline \multirow{2}{*}{\multicolumn{2}{|c|}{ Total }} & $\mathbf{N}$ & 30 & 30 & 30 & 90 & \\
\hline & & $\%$ & $100.0 \%$ & $100.0 \%$ & $100.0 \%$ & $100.0 \%$ & \\
\hline
\end{tabular}

$\mathrm{P}_{1}$ : Control group compared to Chronic liver disease group.

$\mathrm{P}_{2}$ : Control group compared to HCC group.

$\mathrm{P}_{3}$ : Chronic liver disease group compared to HCC group. 
ROLE OF OSTEOPONTIN AND DIKKOPF RELATED PROTEIN -1(DKK-1) AS... 63

In HCC groups, 6 patients (20\%) were classified as stage $\mathrm{B}$, and 24 patients (80\%) were classified as stage C. In CLD groups, 9 patients $(30 \%)$ were classified as stage $\mathrm{B}$, and 20 patients $(70 \%)$ were classified as stage $\mathrm{C}$ (Table 2).

Table(2): Child classification between HCC and CLD.

\begin{tabular}{|c|c|c|c|c|c|c|}
\hline & \multicolumn{2}{|c|}{ GROUPS } & \multirow[t]{2}{*}{ Total } & \multirow[t]{2}{*}{$\mathbf{P}$} \\
\hline & & & CLD & HCC & & \\
\hline \multirow[t]{4}{*}{ Child } & \multirow[t]{2}{*}{ B } & $\mathbf{N}$ & 9 & 6 & 15 & \multirow[t]{4}{*}{0.37} \\
\hline & & $\%$ & $30.0 \%$ & $20.0 \%$ & $25.0 \%$ & \\
\hline & \multirow[t]{2}{*}{$\mathbf{C}$} & $\mathbf{N}$ & 21 & 24 & 45 & \\
\hline & & $\%$ & $70.0 \%$ & $80.0 \%$ & $75.0 \%$ & \\
\hline \multirow{2}{*}{\multicolumn{2}{|c|}{ Total }} & $\mathbf{N}$ & 30 & 30 & 60 & \\
\hline & & $\%$ & $100.0 \%$ & $100.0 \%$ & $100.0 \%$ & \\
\hline
\end{tabular}

The mean of DKK1 in control, CLD, HCC was $1.28 \pm 0.383,1.37 \pm 0.414$, and $2.58 \pm 0.510$ respectively, and there were statistical significant differences between the three groups $\left(\mathrm{p}_{1}<0.05\right),\left(\mathrm{p}_{2,3}<0.001-\right.$ Table 3).

The mean of OPN in control, CLD, HCC was $31.15 \pm 15.031,153.60 \pm 93.931$, $349.83 \pm 183.912$ respectively,there were highly statistical significant differences between the three groups $\left(\mathrm{p}_{1,2,3}<\right.$ 0.001). The mean of AFP in control, CLD, HCC was $1.110 \pm 0.224,34.06 \pm 43.702$, $4666.01 \pm 3938.67$ respectively, there were highly statistical significant differences between the three groups $\left(\mathrm{p}_{1,2,3}<0.001-\right.$ Table 3).

Table (3): Comparison between DKK1, OPN, and AFP as regard control, CLD and HCC groups.

\begin{tabular}{|c|c|c|c|c|c|c|c|}
\hline & & $\mathbf{N}$ & Mean & $\begin{array}{c}\text { Std. } \\
\text { Deviation }\end{array}$ & Minimum & Maximum & $\mathbf{P}$ \\
\hline \multirow{3}{*}{$\begin{array}{l}\text { DKK1 } \\
\text { (ng/ml) }\end{array}$} & Control & 30 & 1.28 & 0.383 & .88 & 2.20 & \multirow{3}{*}{$\begin{array}{l}\mathrm{P}_{1}<0.05 \\
\mathrm{P}_{2}<0.001 \\
\mathrm{P}_{3}<0.001\end{array}$} \\
\hline & CLD & 30 & 1.37 & 0.414 & .90 & 2.30 & \\
\hline & HCC & 30 & 2.58 & 0.510 & 1.80 & 3.30 & \\
\hline \multirow{3}{*}{$\begin{array}{l}\text { OPN } \\
(\mathrm{pg} / \mathrm{ml})\end{array}$} & Control & 30 & 31.15 & 15.031 & 14.50 & 65.00 & \multirow{3}{*}{$\begin{array}{l}\mathrm{P}_{1}<0.001 \\
\mathrm{P}_{2}<0.001 \\
\mathrm{P}_{3}<0.001\end{array}$} \\
\hline & CLD & 30 & 153.60 & 93.931 & 59.00 & 389.00 & \\
\hline & HCC & 30 & 349.83 & 183.912 & 129.00 & 622.00 & \\
\hline \multirow{3}{*}{$\begin{array}{l}\text { AFP } \\
(\mathrm{ng} / \mathrm{ml})\end{array}$} & Control & 30 & 1.110 & 0.224 & .80 & 1.50 & \multirow{3}{*}{$\begin{array}{l}\mathrm{P}_{1}<0.001 \\
\mathrm{P}_{2}<0.001 \\
\mathrm{P}_{3}<0.001\end{array}$} \\
\hline & CLD & 30 & 34.06 & 43.702 & 1.10 & 128.00 & \\
\hline & HCC & 30 & 4666.01 & 3938.67 & 1.80 & 9875.00 & \\
\hline
\end{tabular}

$\mathrm{P}_{1}$ : Control group compared to Chronic liver disease group.

$\mathrm{P}_{2}$ : Control group compared to HCC group.

$\mathrm{P}_{3}$ : Chronic liver disease group compared to HCC group. 
There was a statistical significant positive correlation between the levels of OPN with AFP ( $\mathrm{r}=0.474 \& \mathrm{P}<0.001)$, age $(r=0.196 \& \quad$ \& $=0.64)$, DKK1 $(\mathrm{r}=0.764 \& \mathrm{P}<0.001)$, total bilirubin $(r=0.708 \& \mathrm{P}<0.001)$, AST $(r=0.652 \&$ $\mathrm{P}<$ ALT $(\mathrm{r}=0.637 \& \mathrm{P}<0.001)$, urea $(\mathrm{r}=$ $0.756 \& \mathrm{P}<0.001)$, creatinine $(\mathrm{r}=0.630 \&$ $\mathrm{P}<0.001)$, TLC $(\mathrm{r}=0.490 \& \mathrm{P}<0.001)$ and PT $(r=0.718 \& \mathrm{P}<0.001)$, except for albumin which showed negative significant correlation $(\mathrm{r}=-0.686 \& \mathrm{P}<$ $0.001)$ and platelets which showed negative significant correlation $(\mathrm{r}=0.548$ $\& \mathrm{P}<0.001$ - Table 4).

There was a statistical significant positive correlation between the levels of DKK1with AFP $(r=0.533 \& \mathrm{P}<0.001)$, age $(\mathrm{r}=0.326 \& \mathrm{P}=0.002)$, total bilirubin $(\mathrm{r}=0.675 \& \mathrm{P}<0.001)$, AST $(\mathrm{r}=0.609 \&$ $\mathrm{P}<0.001)$, ALT $(\mathrm{r}=0.620 \& \mathrm{P}<0.001)$, urea $(\mathrm{r}=0.540 \& \mathrm{P}<0.001)$, creatinine $(r=0.620 \& P<0.001)$, TLC $(r=0.564 \&$ $\mathrm{P}<0.001)$ and $\mathrm{PT}(\mathrm{r}=0.714 \& \mathrm{P}<0.001)$ except for albumin which showed negative significant correlation $(\mathrm{r}=-0.648$ $\& \mathrm{P}<0.001)$ and platelets which showed negative significant correlation $(r=-0.366$ $\& \mathrm{P}<0.001$ - Table 4).

Lastly, there was a statistical significant positive correlation between the levels of AFP with age $(\mathrm{r}=0.223 \& \mathrm{P}=0.034)$, total bilirubin $(\mathrm{r}=0.554 \& \mathrm{P}<0.001)$, ALT $(r=0.231 \& P=0.029)$, urea $(r=0.352 \&$ $\mathrm{P}<0.001)$, creatinine $(\mathrm{r}=0.216 \& \mathrm{P}=0.04)$, TLC $(r=0.453 \& \mathrm{P}<0.001), \mathrm{PT}(\mathrm{r}=0.615$ $\& \mathrm{P}<0.001)$ except for albumin which showed negative significant correlation $(\mathrm{r}=-0.485 \& \mathrm{P}<0.001)$ and platelets which also showed negative significant correlation $(\mathrm{r}=-0.312 \& \mathrm{P}=0.003$ - Table 4).

Table (4): Spearman's Correlation between DKK, OPN, AFP and other parameters in HCC group.

\begin{tabular}{|c|c|c|c|c|}
\hline & & DKK1 & OPN & AFP \\
\hline \multirow[t]{2}{*}{ OPN (ng/ml) } & $\mathrm{R}$ & .764 & 1 & .474 \\
\hline & $\mathrm{P}$ & .000 & & .000 \\
\hline \multirow[t]{2}{*}{$\mathrm{AFP}(\mathrm{ng} / \mathrm{ml})$} & $\mathrm{R}$ & .533 & .474 & 1 \\
\hline & $\mathrm{P}$ & .000 & .000 & \\
\hline \multirow[t]{2}{*}{ Age (Years) } & $\mathrm{R}$ & .326 & .196 & .223 \\
\hline & $\mathrm{P}$ & .002 & .064 & .034 \\
\hline \multirow[t]{2}{*}{$\operatorname{TLC}\left(\mathrm{mm}^{3} / \mathrm{x} 10^{3}\right)$} & $\mathrm{R}$ & .564 & .490 & .453 \\
\hline & $\mathrm{P}$ & .000 & .000 & .000 \\
\hline \multirow[t]{2}{*}{ PLT $\left(\mathrm{mm}^{3} / \mathrm{x} 10^{3}\right)$} & $\mathrm{R}$ & $-.366-$ & -.548 & $-.312-$ \\
\hline & $\mathrm{P}$ & .000 & .000 & .003 \\
\hline \multirow[t]{2}{*}{ PT (Second) } & $\mathrm{R}$ & .714 & .718 & .615 \\
\hline & $\mathrm{P}$ & .000 & .000 & .000 \\
\hline \multirow[t]{2}{*}{ Creatinine $(\mathrm{mg} / \mathrm{dl})$} & $\mathrm{R}$ & .620 & .630 & .216 \\
\hline & $\mathrm{P}$ & .000 & .000 & .041 \\
\hline \multirow[t]{2}{*}{ Urea $(\mathrm{mg} / \mathrm{dl})$} & $\mathrm{R}$ & .540 & .756 & .352 \\
\hline & $\mathrm{P}$ & .000 & .000 & .001 \\
\hline \multirow[t]{2}{*}{$\operatorname{AST}(\mathrm{u} / \mathrm{l})$} & $\mathrm{R}$ & .609 & .652 & .183 \\
\hline & $\mathrm{P}$ & .000 & .000 & .085 \\
\hline \multirow[t]{2}{*}{$\operatorname{ALT}(\mathrm{u} / \mathrm{l})$} & $\mathrm{R}$ & .620 & .637 & .231 \\
\hline & $\mathrm{P}$ & .000 & .000 & .029 \\
\hline \multirow[t]{2}{*}{ Albumin (g/dl) } & $\mathrm{R}$ & $-.648-$ & $-.686-$ & $-.485-$ \\
\hline & $\mathrm{P}$ & .000 & .000 & .000 \\
\hline \multirow[t]{2}{*}{ Bilirubin $(\mathrm{mg} / \mathrm{dl})$} & $\mathrm{R}$ & .675 & .708 & .554 \\
\hline & $\mathrm{P}$ & .000 & .000 & .000 \\
\hline
\end{tabular}


ROLE OF OSTEOPONTIN AND DIKKOPF RELATED PROTEIN -1(DKK-1) AS... 65

DKK1 and OPN levels were while AFP level was non-significant $(\mathrm{P}=$ significantly higher in metastasis cases 0.424 - Table 5).

than non metastatic cases $(\mathrm{P}<0.001)$,

Table(5): Comparison between metastasis cases among HCC group as regard DKK1, OPN and AFP.

\begin{tabular}{|l|c|c|c|c|c|}
\hline & Metastasis & $\mathbf{N}$ & Mean & Std. Deviation & P \\
\hline \multirow{2}{*}{$\begin{array}{l}\text { DKK1 } \\
(\mathrm{pg} / \mathrm{ml})\end{array}$} & $+\mathrm{VE}$ & 15 & 3.006 & 0.243 & $\mathrm{P}<0.001$ \\
\cline { 2 - 5 } & $-\mathrm{VE}$ & 15 & 2.16 & 0.311 & \\
\hline \multirow{2}{*}{ OPN (ng/ml) } & $+\mathrm{VE}$ & 15 & 506.26 & 127.484 & \multirow{2}{*}{$\mathrm{P}<0.001$} \\
\cline { 2 - 5 } & $-\mathrm{VE}$ & 15 & 193.40 & 37.047 & \\
\hline \multirow{2}{*}{ AFP $(\mathrm{ng} / \mathrm{ml})$} & $+\mathrm{VE}$ & 15 & 4079.13 & 3422.202 & \multirow{2}{*}{$\mathrm{P}=0.424$} \\
\cline { 2 - 5 } & $-\mathrm{VE}$ & 15 & 5252.89 & 4436.772 & \\
\hline
\end{tabular}

Patients with large tumor size have while non significantly differrent as significantly higher OPN levels $\mathrm{P}=0.025$, regard AFP and DKK1 levels (Table 6).

Table (6): Comparison between tumor size among HCC as regard DKK1, OPN and AFP.

\begin{tabular}{|l|c|c|c|c|c|}
\hline & Size & $\mathbf{N}$ & Mean & Std. Deviation & P \\
\hline \multirow{2}{*}{ DKK1 $(\mathrm{pg} / \mathrm{ml})$} & $>5$ & 21 & 2.564 & 0.621 & \multirow{2}{*}{0.930} \\
\cline { 2 - 5 } & $<5$ & 9 & 2.54 & 0.364 & \\
\hline \multirow{2}{*}{ OPN (ng/ml) } & $>5$ & 21 & 398.04 & 192.18 & \multirow{2}{*}{0.025} \\
\cline { 2 - 5 } & $<5$ & 9 & 237.33 & 99.65 & \\
\hline \multirow{2}{*}{ AFP (ng/ml) } & $>5$ & 21 & 4627.17 & 4043.93 & \multirow{2}{*}{0.936} \\
\cline { 2 - 5 } & $<5$ & 9 & 4756.64 & 3916.46 & \\
\hline
\end{tabular}

The Area Under the Curve for DKK1, OPN and AFP was 0.970, 0.930 and 0.910 and cut off values were $>1.75,>164.5$ and $>7.15$ respectively (Table 7 ).

Table (7): Area under the curve and cut off value of DKK1, OPN and AFP.

\begin{tabular}{|c|c|c|c|c|}
\hline \multirow{2}{*}{$\begin{array}{l}\text { Test Result } \\
\text { Variable(s) }\end{array}$} & \multirow[b]{2}{*}{ Area } & \multirow[b]{2}{*}{ Cutoff } & \multicolumn{2}{|c|}{ 95\% Confidence Interva } \\
\hline & & & $\begin{array}{l}\text { Lower } \\
\text { Bound }\end{array}$ & $\begin{array}{l}\text { Upper } \\
\text { Bound }\end{array}$ \\
\hline DKK1 & 0.970 & $>1.75$ & .941 & .999 \\
\hline OPN & 0.930 & $>164.5$ & .879 & .981 \\
\hline AFP & 0.910 & $>7.15$ & .840 & .980 \\
\hline
\end{tabular}


The sensitivity, specificity, positive predictive value and negative predictive value of DKK1, OPN were higher than AFP. The combination of AFP and DKK1 has increased both sensitivity and specificity of AFP for detection of HCC. The combination of AFP and OPN has increased specificity of AFP for detection of HCC to $95 \%$ but decreased sensitivity to $76.7 \%$. The combination of OPN and DKK1has increased both sensitivity and specificity for detection of HCC to $83.3 \%$ and $96.6 \%$ respectively (Table 8 ).

Table (8): Sensitivity and specificity of DKK, OPN and AFP..

\begin{tabular}{|l|c|c|c|c|c|}
\hline & Sensitivity & Specificity & +VE predictive & -VE predictive & Accuracy \\
\hline DKK1 & $86.7 \%$ & $88.3 \%$ & $78.7 \%$ & $92.9 \%$ & $87.7 \%$ \\
\hline OPN & $90.0 \%$ & $90.0 \%$ & $81.8 \%$ & $94.7 \%$ & $90.0 \%$ \\
\hline AFP & $80.0 \%$ & $55.0 \%$ & $47.05 \%$ & $84.6 \%$ & $63.3 \%$ \\
\hline AFP \& DKK1 & $83.3 \%$ & $93.3 \%$ & $86.2 \%$ & $91.8 \%$ & $90.0 \%$ \\
\hline AFP \& OPN & $76.7 \%$ & $95.0 \%$ & $88.4 \%$ & $89.0 \%$ & $88.8 \%$ \\
\hline OPN \& DKK1 & $83.3 \%$ & $96.6 \%$ & $87.5 \%$ & $90.9 \%$ & $93.3 \%$ \\
\hline
\end{tabular}

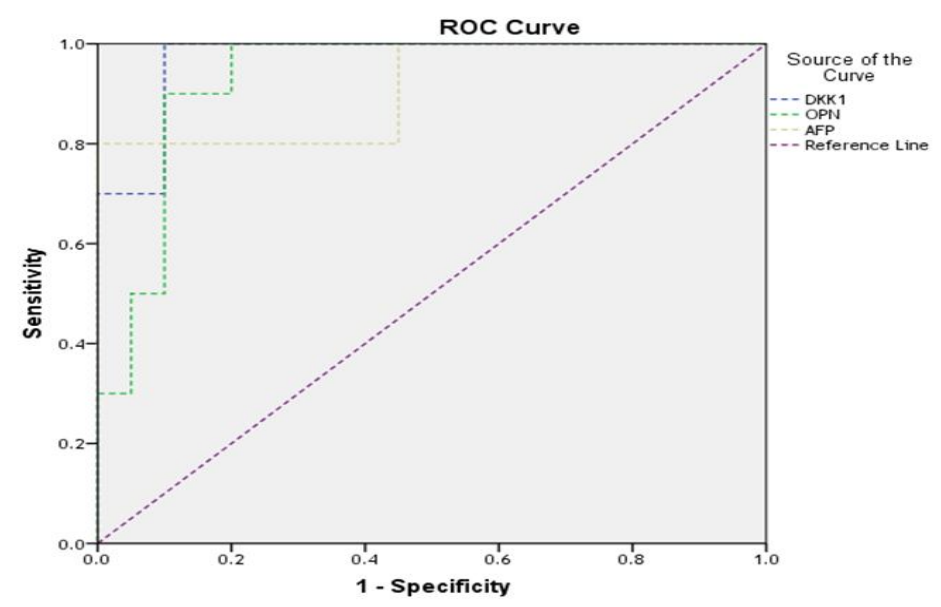

Figure (1): ROC Curve for detection of HCC markers cut off values.

\section{DISCUSSION}

Hepatocellular carcinoma is an increasingly prevalent clinical problem worldwide and is the third most common cause of cancer-related death (Venook et al., 2010).

Owing to the lack of reliable clinical HCC markers, fewer than $20 \%$ of patients are diagnosed at a stage where curative treatment can be performed. In most cases HCC is diagnosed at a late stage, and often arises in a background of chronic liver disease and cirrhosis. Therefore, the prognosis of patients with HCC is generally poor with the 5-year survival rate for this malignancy is depressingly 


\section{ROLE OF OSTEOPONTIN AND DIKKOPF RELATED PROTEIN -1(DKK-1) AS... 67}

low, ranging from 4-6\% in different countries (El-Garem et al., 2013).

The aim of the present study was to evaluate the role of serum OPN level and Dickkopf-1(DKK1) as potential markers of HCC among HCV infected patients, compared to AFP. Also, its relationship with clinicopathological features of HCC patients.

As regards the sex of patients, in our study the male to female ratio in HCC group was 1.5: 1(60\% males and 40\% females with HCC). The reasons for higher rates of liver cancer in males may be explained by differences in exposure to risk factors. However, sex hormones and other x-linked genetic factors may also be important but there was no significant difference as regard sex. It has been speculated that estrogens and androgens could modulate hepatocarcinogenesis and explain the higher incidence of HCC in men (El-Zayadi et al., 2005).

These results were in agreement with those obtained by Salem et al. (2013) who reported in HCC patients a male: female ratio was 2: 1 , this male predominance was also observed by Goldman and Ausiello (2004) who reported a male: female ratio 2:1 up to 4:1. In Keddeas and Abo-shady (2011) it was reported that $\mathrm{HCC}$ is three times more common in men than women.

Our results showed that there were highly significant differences among groups as regard OPN, Dickkopf1 and AFP markers highest in HCC followed by CLD followed by normal levels in control groups.

The sensitivity of DKK1, OPN and AFP was $86.7 \%, 90.0 \%$ and $80.0 \%$ respectively. When AFP was combined with DKK1, sensitivity increased to 83.3\%. When AFP was combined with OPN, sensitivity decreased to $76.7 \%$.
When OPN was combined with DKK1, sensitivity was $83.3 \%$.

The specificity of DKK1, OPN and AFP was $88.3 \%, 90.0 \%$ and $55.0 \%$ respectively. When AFP combined with DKK1, specificity increased to $93.3 \%$. When AFP combined with OPN, specificity increased to $95.0 \%$. When OPN was combined with DKK1, specificity increased to $96.6 \%$.

These results were similar with those of Salem et al. (2013) who found that significant elevation of plasma osteopontin levels and AFP levels in HCC patients than HCV patients' levels and lower levels in normal control group.

Fouad et al. (2015) also reported that there was a statistically significant increase in the serum OPN levels in the HCC group compared to the benign chronic liver disease groups (HCV without cirrhosis, HCV with cirrhosis, Fatty liver disease), healthy subjects, OPN was superior to AFP in the selective detection, diagnosis of HCC and in predicting liver cirrhosis. El-Din Bessa et al. (2010) also found that: plasma levels of OPN and AFP in HCC cirrhotic patients being significantly higher than in cirrhotic patients without HCC and healthy controls.

In our study, the median serum OPN level with small tumor size $<5 \mathrm{~cm}$ was $237.33 \mathrm{ng} / \mathrm{mL}$, and with large tumor size $>5 \mathrm{~cm}$ was $398.04 \mathrm{ng} / \mathrm{mL}$ and this was statistically significant.

This was in agreement with Salem et al. (2013) who found that tumors $<3 \mathrm{~cm}$, present in $40 \%$ of patients, showed median plasma OPN level 140 with a range of $(100-336 \mathrm{ng} / \mathrm{mL})$, and tumors $\geq$ $3 \mathrm{~cm}$, present in $60 \%$ of patients, showed median plasma OPN level 229 with a range of (131 - $438 \mathrm{ng} / \mathrm{mL})$ ( $\mathrm{P}$ value: 0.28). However, Abu El-Makarem et al. 
(2011) reported that the median plasma OPN level in tumors $<5 \mathrm{~cm}$ was 510 $\mathrm{ng} / \mathrm{mL}$ and in and tumors $\geq 5 \mathrm{~cm}$ was 1230 , and this was statistically significant.

The present study showed that OPN was significantly higher among cases with lymph node metastasis than those with no metastasis. These results were in accordance with Abu El-Makarem et al. (2011) reported that the median plasma OPN level in patients with lymph node metastasis $(1423 \mathrm{ng} / \mathrm{mL})$ was higher than patients with no lymph node metastasis (497ng/ml).

In our study, there was a statistical significant positive correlation between the levels of AFP and OPN, and this was in agreement with that of Salem et al. (2013) who found that there was significant positive correlation between OPN and AFP. However, Sun et al. (2009) found that the correlation between plasma OPN and serum AFP was insignificant and, therefore, they had stated that plasma OPN levels might be helpful for the diagnosis of HCC in the patients with non-diagnostic AFP level.

In our study, the sensitivity, specificity, PPV and NPV of serum OPN levels in HCC patients were 90, 90, 81.8, and 94.7 respectively at a cut-off value $>164.5$. AUC for OPN was 0.930 with CI (0.8790.981).

For AFP at a cut-off value $>7.15 \mathrm{ng} / \mathrm{ml}$, the value of sensitivity, specificity, PPV and NPV of serum AFP levels in HCC patients relative to the CLD group were $80.00 \%, 45.0 \%, 47.05$ and 84.6 respectively. AUC for AFP was 0.910 with CI $(0.840-0.980)$.

Results of our study were in agreement with the study done by El-Din Bessa et al. (2010) who reported that, the sensitivity and specificity of OPN for HCC diagnosis were $88.3 \%$ and $85.6 \%$, respectively, at a cut-off value of 9.3 $\mathrm{ng} / \mathrm{mL}$ with OPN having a greater AUC value (0.918) than AFP (0.712).

Many studies reported better diagnostic accuracy of OPN over AFP in HCC diagnosis. Abohalima and Salem (2014) found that OPN AUC for HCC diagnosis was 0.991 (95\% CI: 0.948 to 1.000$)$ and it differed significantly $(\mathrm{p}=0.01)$ from AFP AUC (0.889, 95\% CI: 0.810 to 0.943$)$. At a cut off value of OPN >178 ng/ml, the test had sensitivity of $98 \%$ and specificity of $96 \%$ while AFP at a cutoff value of $>185 \mathrm{ng} / \mathrm{ml}$ had sensitivity and specificity of $86 \%$ and $94 \%$ respectively in HCC diagnosis.

In contrary to our results, the plasma levels of OPN show low diagnostic accuracy for HCC compared to AFP. However, OPN may have a complementary role in diagnosing $\mathrm{HCC}$ in patients with non-diagnostic levels of AFP (AlZoubi et al., 2017).

There was a highly significant difference between patient and control groups as regard DKK1. This result was in line with that of who reported high expression of DKK1 in HCC (Yamashita et al., 2008).

There was no significant difference among patient groups as regard size of lesion. This result was in line with that of Yu et al. (2009) who reported that there is no correlation between DKK1-positivity and tumor size. On the other hand Shen et al. (2012) stated that there is a correlation between serum DKK1 level and a larger tumor size $(\geq 5 \mathrm{~cm})$. Gomceli et al. (2012) reported that DKK1 may have a substantial role is in patients where AFP levels are negative or equivocal such as the case in chronic liver disease.On contrary to our results, Yang et al. (2004) stated that dickkopf-1 (Dkk1) is significantly elevated in nodular HCC (multiple lesion) with high metastatic 
ROLE OF OSTEOPONTIN AND DIKKOPF RELATED PROTEIN -1(DKK-1) AS... 69

potential compared to solitary HCC (solitary lesion).

Fatima et al. (2014) found that in comparison to serum $\alpha$-fetoprotein (AFP) level, which remains the gold standard for HCC diagnosis, high serum DKK1 levels have higher diagnostic value for $\mathrm{HCC}$, especially for AFP-negative $\mathrm{HCC}$, and can distinguish HCC from non-malignant chronic liver diseases.

AFP concentrations raised in 11-58\% of patients with chronic hepatitis or cirrhosis in the absence of HCC. Therefore, measurement of DKK1 in serum can help to make a differential diagnosis of HCC in patients in these high-risk populations.

Yu et al. (2009) found that although elevated levels of AFP remain the gold standard for screening $\mathrm{HCC}$, there are, however, a subgroup of patients who have HCC and normal levels of AFP. When patients were stratified according to AFP levels, DKK1 over expression demonstrated worse prognosis for AFP-normal HCC patients, suggesting that DKK1 may serve as a prognostic marker for this group of patients.

Our study showed that there was high levels of OPN and DKK1 in metastatic cases compared to non-metastatic ones with statistical significant difference $\mathrm{P}<0.001$

\section{CONCLUSION}

1. OPN and DKK1can be used for diagnosis of $\mathrm{HCC}$ and differentiation between HCC and CLD.

2. OPN and DKK1have higher sensitivity and specificity than AFP and can be used for early diagnosis of HCC.

3. OPN and DKK1can be used for differentiation between metastatic and non-metastatic HCC.

\section{REFERENCES}

1. Abohalima AS and Salem HM (2014): Osteopontin as hepatocellular carcinoma marker in $\mathrm{HCV}$ related liver cirrhosis. Life Science Journal; 1.

2. Abu El Makarem MA, Abdel-Aleem A, AliA, Saber R, Shatat M, Rahem DA and Sayed D (2011): Diagnostic significance of plasma osteopontin in hepatitis $\mathrm{C}$ virus-related hepatocellular carcinoma. Ann Hepatol; 10: 296-305.

3. Al-Zoubi S, Wassou $\mathrm{fA}$, and Zetoune AB (2017): Measuring Levels of Osteopontin as a potential biomarker for Hepatocellular Carcinoma in Syrian patients. Gastroenterology and Hepatology from bed to bench; 4: 123-29.

4. El-Din Bessa SS, Elwan NM, Suliman GA and El-Shourbagy SH (2010): Clinical significance of plasma osteopontin level in Egyptian patients with hepatitis $\mathrm{C}$ virus-related hepatocellular carcinoma. Arch Med Res; 41(7): 541-547.

5. El-Garem H, Abdel-Hafez H, Foaud A, Al Akel W, Eldien Atia M, Wang VW, Mok SC, Smith DI and Berkowitz RS (2013): Tissue biomarkers in the early detection of hepatocellular carcinoma among Egyptian patients with chronic hepatitis C: A possible genetic profile. Br J Med Med Res; 3: 18581870 .

6. El-Zayadi AR, Badran HM, Barakat EM, Attia MD, Shawky S, Mohamed MK, Selim $O$ and Saeid A (2005): Hepatocellular carcinoma in Egypt: a single center study over a decade. World J Gastroenterol; 11: 51935198.

7. Fatima S, John ML, Ronnie TP and Nikki PL (2014): Dysregulated expression of dickkopfs for potential detection of hepatocellular carcinoma. Liver International; 14 (5): 535548.

8. Fouad SA, Mohamed NA, Fawzy MF, Doaa A, Moustafa DA, Cheung TH, Wong RR, Yim SF and Ng MH (2015): Plasma osteopontin level in chronic liver disease and hepatocellular carcinoma. Hepat Mon; 15(9): 307. 
9. Goldman L and Ausiello D (2004): Hepatocellular carcinoma. In: Arend, Armitage, Drazen, Gill, Griggs, Powell, Scheld. Cecil Textbook of Medicine, Elsevier, Holland; 4(22): 1224-1225.

10. Gomceli I, Bostanci EB, Ozer I, Tam FC, Chung TK and Wong YF (2012): A novel screening biomarker in gastric cancer: serum Dickkopf-1. Hepato Gastroenterology; 59: 1661-4.

11. Keddeas MW and Abo-shady RA (2011): Evaluation of plasma osteopontin level as a biomarker for hepatocellular carcinoma in Egyptian patients. Egyptian Liver Journal; 1: 38-42.

12. Lehman EM and Wilson ML (2009): Epidemiology of hepatitis virusesamong hepatocellular carcinoma cases and healthy peoplein Egypt: a systematic review and metaanalysis. Int J Cancer; 124(3): 690-7.

13. Salem M, Abdel Atti S, El Raziky M, Darweesh SK and El Sharkawy M (2013): Clinical Significance of Plasma Osteopontin Level as a Biomarker of Hepatocellular Carcinoma. Gastroenterology Research; 6(5):191-199.

14. Shaker MK, Abdella HM, Khalifa MO and Dorry AE (2013): Epidemiological characteristics of hepatocellular carcinoma in Egypt: a retrospective analysis of 1313 cases. Liver International; 33(10): 1601-1606.

15. Shen Q, Fan J, Yang XR, Chan PK, Cheung TH and Yim SF (2012): Serum DKK1 as a protein biomarker for the diagnosis of hepatocellular carcinoma: a large-scale, multicenter study. Lancet Oncol; 13: 817-26.

16. Sun HY, Li Y, Guo K, Kang XN, Sun C and Liu YK (2011): Identification of metastasisrelated osteopontin expression and glycosylation in hepatocellular carcinoma. Zhonghua Gan Zang Bing Za Zhi; 19: 904907.

17. Sun J, Xu HM, Zhou HJ, Mac Conaill LE, Doran G and Pedamallu CS (2009): The prognostic significance of preoperative plasma levels of osteopontin in patients with TNM stage-1 of hepatocellular carcinoma. J Cancer Res Clin Oncol; 135(1): 10-15.

18. Venook AP, Papandreou C, Furuse J, and de Guevara LL (2010): The incidence, epidemiology of hepatocellular carcinoma: a global and regional perspective. Oncologist; 15 (4): 5-13.

19. Yamashita T, Forgue M, Wang W, Kim JW, Ye Q, Jia H, Ojesina AI, Wong RR and Wang VW (2008): EpCAM and alphafetoprotein expression defines novel prognostic subtypes of hepatocellular carcinoma. Cancer Res; 68: 1451-1461.

20. Yang H, Chen GD, Fang F, Liu Z, Lau SH, Zhang JF and Yang LY (2012): Dickkopf-1: as a diagnostic and prognostic serum marker for early hepatocellular carcinoma. The International Journal of Biological Markers; 28(3): 286-297.

21. Yang M, Ramachandran A, Yan HM, Woolbright BL, Copple BL, Freeman SS, Lau TS, Kwong J and Chan LK (2014): Osteopontin is an initial mediator of inflammation and liver injury during obstructive cholestasis after bile duct ligation in mice. Toxicol Lett; 224: 186-195.

22. Yang LY, Wang W, Peng JX, Fromer M, May T, Worley MJ Jr and Esselen KM (2004): Differentially expressed genes between solitary large hepatocellular carcinoma and nodular hepatocellular carcinoma. World Journal of Gastroenterology; 10: 3569-73.

23. Yu B, Yang X, Xu Y, Elias KM, Lawrence M, Getz G, Smith DI and Crum CP (2009): Elevated expression of DKK1 is associated with cytoplasmic/nuclear beta-catenin accumulation and poor prognosis in hepatocellular carcinomas. J Hepatol; 50: 94857. 


\section{دور الأستيوبنتين و البروتين المرتبط بالديكوف ـ اكدلالات}

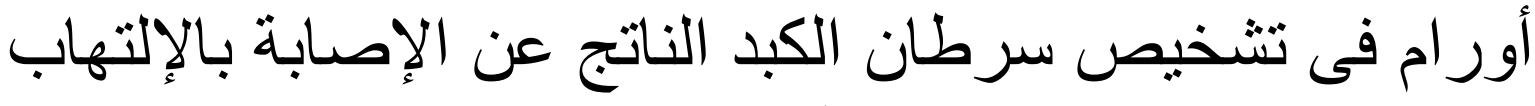
الكبدى

$$
\text { الفيروسى سىى }
$$

عبد اللاه أبو سريع عمر*ـ أثرف طه عبد المطلب*** إبراهيم متولى بيومى*** ****** جمال محمد سليمان

*قسم الكيمياء الحيوية الطبيةـ كلية الطب- جامعة الأزهر

**قسم الكيمياء الحيوية الطبيةـ وحدة الإخصاب الطبى المساعدـ المركز الدولى الإسلامى - جامعة الأزهر الأهر

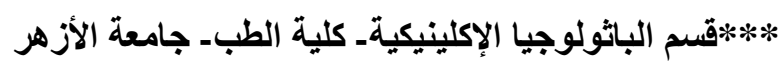

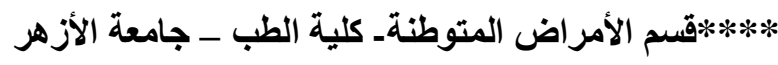

خلقية البحث: يعتبر الأسوتيوبونتين من دلالات الأور ام الهامـة، حيث أنه من المصفوفات المتجمدة

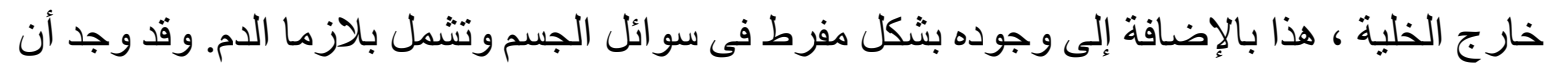

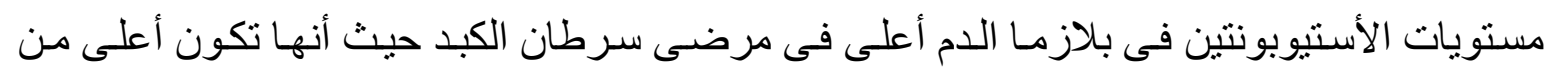

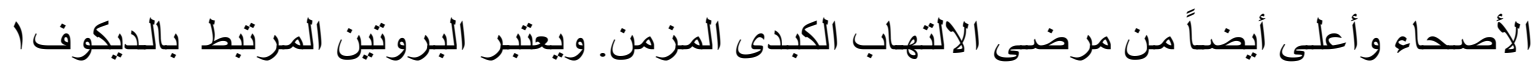
علامة مصلية للتشخيص والإنذار المبكر لسرطان الكبد. وقد وجد أن الرسول الرنا للبروتين المرتبط بالديكوف ا يرتفع أيضاً فى الإصابة المبكرة بسرطانات الكبد.

الهـف من البحث: هو التحقق من إمكانية استخدام مستوى الأستيوبونتين و الديكوف ا بوصفها علامـة بيولوجية و أهميتهما الإكلينيكية كدلالة قوية لتشخيص مرضي سرطان الكبد مقارنة ب ألفا فيتوبروتين. وكذا علاقتهما بالأعر اض الإكلينيكية و الباتولوجية لمرضى سرطيه لهان الكبد.

مواد وطرق البحث: اشتملت هذه الدر اسة على تسعين شخصا تم تقسيمه الى ثلاث مجمو عات: المجموعة الأولى: ثلاثون مريضـا و تشـل المرضـى المصـابين بسرطان الكبد الناتج عن الإصـابة

$$
\text { بالالتهاب الكبدى الفيروسى سي. }
$$

المجموعة الثانية: وتثمل ثلاثون مريضا مصابون بالالتهاب الكبدى المزمن. المجموعة الثالثة: وتشمل ثناثون شخصا من الأشخاص الأصحاء ليكونوا المجموعة الضابطة .

وقد تم قياس الديكوف او الفا فيتو بروتين و الأستيوبونتين بطريقة الاليزا.

التتـائج: كـان هنـاك فـروق ذات دلالــة إحصـائية في مسـتويات الـديكوف ا و الأسـتيوبونتين بـين 
المجمو عات التى تم در استها. كمـا وجد أن مستويات الديكوف ا والأستيوبونتين تكون مرتفعة فى مرضى سرطان الكبد المصاحب بثانويات عن غير المصاحب بثانويات، بينما لم يختلف مستوى ألفا

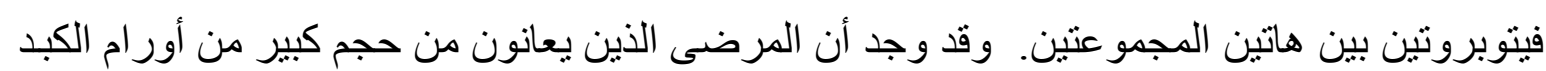
يرتفع مستوى الأستيوبونتين لهم، بينما لم يختلف مستويات الديكوف الو والألفا فيتوبروتين.

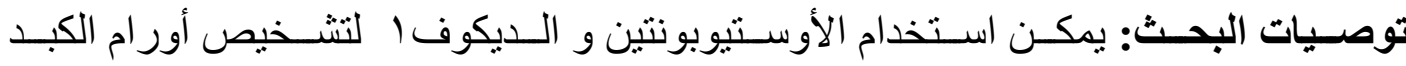

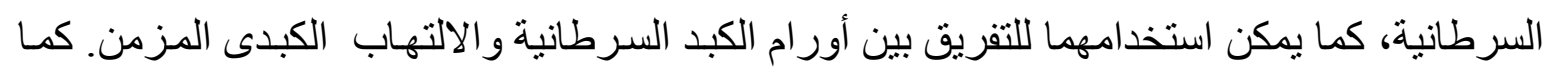

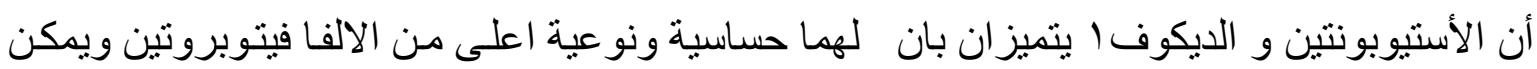

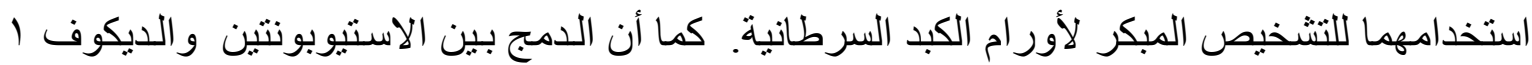
ينتج عنه زيادة النوعية والحساسية للتشخيص المبكر لأورام الكبد السرطانية. 